ANDRZEJ PASEK

ORCID: 0000-0001-9468-5204

Uniwersytet Wrocławski

andrzej.pasek@uwr.edu.pl

\title{
Przestępstwa przeciwko zrzeszeniom prawa publicznego w projekcie kodeksu karnego Komisji Kodyfikacyjnej Rzeczypospolitej Polskiej
}

W dekrecie z dnia 14 listopada 1918 roku Józef Piłsudski zdecydowanie podkreślił tymczasowy charakter powołanego na jego podstawie rządu aż do zwołania Sejmu Ustawodawczego w możliwie krótkim, kilkumiesięcznym terminie. Wezwał także Prezydenta Ministrów, żeby przedłożył mu projekt utworzenia najwyższej władzy reprezentacyjnej Republiki Polskiej funkcjonującej w okresie przejściowym $^{1}$. Na tej podstawie Tymczasowy Rząd Ludowy Republiki Polskiej uchwalił projekt utworzenia najwyższej władzy reprezentacyjnej Republiki Polskiej aż do czasu zwołania Sejmu Ustawodawczego, zatwierdzony następnie przez Józefa Piłsudskiego². W myśl art. 1 dekretu z dnia 22 listopada 1918 roku Józef Piłsudski objął, jako Tymczasowy Naczelnik Państwa, „Najwyższą Władzę Republiki Polskiej” i sprawował ją aż do zwołania Sejmu Ustawodawczego. W celu przeprowadzenia elekcji wydany został dekret z dnia 28 listopada 1918 roku o ordynacji wyborczej do Sejmu Ustawodawczego ${ }^{3}$.

Dostrzeżono także problem ochrony ustalonego w ordynacji procesu wyborczego oraz funkcjonowania organu przedstawicielskiego na gruncie prawa karnego.

1 Dekret Naczelnego Dowódcy Józefa Piłsudskiego z dnia 14 listopada 1918 roku (Dziennik Praw Państwa Polskiego z 1918 r. Nr 17, poz. 40; dalej: Dz. Praw P. Pol.).

2 Dekret z dnia 22 listopada 1918 roku o najwyższej władzy reprezentacyjnej Republiki Polskiej (Dz. Praw P. Pol. z 1918 r. Nr 17, poz. 41).

${ }^{3}$ Dekret z dnia 28 listopada 1918 roku o ordynacji wyborczej do Sejmu Ustawodawczego (Dz. Praw P. Pol. z 1918 r. Nr 18, poz. 46). 
Dekret z dnia 8 stycznia 1919 roku o postanowieniach karnych za przeciwdziałanie wyborom do Sejmu i wykonywaniu obowiązków poselskich ${ }^{4}$ przewidywał sankcje karne za: 1. przeszkadzanie wyborcy w urzeczywistnianiu prawa wolnego wyboru do Sejmu; 2. podburzanie do przeciwdziałania wyborom; 3. nakłanianie wyborcy do głosowania na rzecz wskazanej osoby; 4. przeszkadzanie w czynnościach zebrań przedwyborczych i komisji wyborczych; 5. nieuprawnione branie udziału w wyborach; 6. nadużycia przy przyjmowaniu i obliczaniu głosów wyborczych; 7. przestępstwa przeciwko dokumentom wyborczym; 8. niedopuszczenie posła do wykonywania obowiązków związanych z jego mandatem; 9. przeszkadzanie czynnościom Sejmu ${ }^{5}$. W myśl art. 8 tego dekretu

winny niedopuszczenia posła do Sejmu — za pomocą gwałtu na osobie, groźby karalnej, podstępu lub nadużycia władzy — do wykonania obowiązków związanych z jego mandatem, ulegnie karze: więzienia na czas od lat 3-ch do 6-ciu (dom poprawy).

Przepis art. 9 stanowił, że

winny przeszkodzenia czynnościom Sejmu za pomocą gwałtu na osobie, groźby karalnej, podstępu, uszkodzenia lokalu Sejmu albo sztucznego zanieczyszczenia powietrza w tym lokalu, ulegnie karze: więzienia na czas od lat 3-ch do 6-ciu (dom poprawy). Jeżeli przestępstwo zostało spełnione przez kilka osób uzbrojonych, to winni ulegną karze ciężkiego więzienia na czas od lat 8-miu do lat 10 -ciu.

Dekret z dnia 8 stycznia 1919 roku został uchylony art. $5 \S 1$ pkt 2 rozporządzenia Prezydenta Rzeczypospolitej z dnia 11 lipca 1932 roku Przepisy wprowadzające kodeks karny i prawo o wykroczeniach ${ }^{6}$, albowiem przestępstwa przeciwko zrzeszeniom prawa publicznego zostały ujęte w rozdziale XIX rozporządzenia Prezydenta Rzeczypospolitej z dnia 11 lipca 1932 roku Kodeks karny (dalej: kodeks, k.k. ${ }^{7}$. Do zrzeszeń tych zaliczono: Sejm, Senat, Zgromadzenie Narodowe i Sejm autonomiczny. Przepis art. 114 k.k. dotyczył wywierania wpływu przemocą lub groźbą bezprawną na czynności tych organów lub przeszkadzania tym czynnościom. W art. 115 rozszerzono tę ochronę na analogiczne czynności innego niż określone $\mathrm{w}$ art. 114 zrzeszenia prawa publicznego. $\mathrm{Z}$ kolei w art. 116 unormowano wywieranie wpływu przemocą lub groźbą bezprawną na wykonywanie mandatu posła, senatora lub członka Sejmu autonomicznego bądź przeszkadzanie temu wykonywaniu ${ }^{8}$. Ostatni w tym rozdziale art. 117 udzielał takiej samej ochrony

${ }^{4}$ Dekret z dnia 8 stycznia 1919 roku o postanowieniach karnych za przeciwdziałanie wyborom do Sejmu i wykonywaniu obowiązków poselskich (Dz. Praw P. Pol. z 1919 r. Nr 5, poz. 96).

5 J. Koredczuk, Przestepstwa przeciwko wyborom i glosowaniu w polskim prawie karnym XX wieku, „Opolskie Studia Administracyjno-Prawne” 14, 2016, nr 2, s. 221.

${ }^{6}$ Rozporządzenie Prezydenta Rzeczypospolitej z dnia 11 lipca 1932 roku Przepisy wprowadzające kodeks karny i prawo o wykroczeniach (Dz.U. RP z 1932 r. Nr 60, poz. 573).

7 Rozporządzenie Prezydenta Rzeczypospolitej z dnia 11 lipca 1932 roku Kodeks karny (Dz.U. RP z 1932 r. Nr 60, poz. 571).

8 J. Koredczuk, op. cit., s. 223. 
wykonywaniu mandatu członka zrzeszenia prawa publicznego innego niż określone $\mathrm{w}$ art. 116.

Zawarte w rozdziale XIX k.k. stany faktyczne zostały skonstruowane w ramach prac prowadzonych przez Komisję Kodyfikacyjną Rzeczypospolitej Polskiej (dalej: KKRP) ${ }^{9}$ nad projektem polskiego kodeksu karnego. Ich podstawą były referaty Wacława Makowskiego i Juliusza Makarewicza Ochrona karna trybu ustawodawstwa i postępowania wyborczego, wygłoszone na posiedzeniach sekcji prawa karnego materialnego w Warszawie w dniu 20 i 21 stycznia 1925 roku $^{10}$. W rozważaniach nad tymi referatami oraz podejmowanymi następnie uchwałami uczestniczyli, oprócz referentów, pozostali członkowie sekcji prawa karnego: Franciszek Falkiewicz, Juliusz Kałużniacki, Witold Prądzyński i Stanisław Śliwiński ${ }^{11}$.

Wacław Makowski wskazał w swoim wystąpieniu, że ochrona karna trybu ustawodawstwa była stosunkowo nowym rozwiązaniem prawnym, związanym ściśle z zasadą podziału władzy, wyodrębnieniem ustawodawstwa oraz przekazaniem go zbiorowości obywateli działających za pośrednictwem swoich przedstawicieli lub bezpośrednio (referendum, plebiscyt). W postępowaniu ustawodawczym wyodrębnił dwa elementy: właściwe czynności ustawodawcze reprezentacji narodowej oraz wybory tej reprezentacji i głosowanie ludowe (plebiscyt) ${ }^{12}$.

Referent zaznaczył, że działanie polegające na trwałej eliminacji ustanowionego prawnie organu ustawodawczego stanowiłoby formę zamachu na ustrój państwa, a więc należałoby do grupy zbrodni stanu. Natomiast ochrona funkcjonowania reprezentacji narodowej dotyczyła tylko działań skierowanych przeciwko poszczególnym czynnościom izby lub izb ustawodawczych. Kwestia przedmiotu zamachu mogła tu być traktowana w dość zróżnicowany sposób. Nie ulegało wątpliwości, że dążenie do uniemożliwienia wykonywania obowiązków wynikających z udziału w organach przedstawicielskich stanowiło istotę stanów faktycznych przestępstw przeciwko postępowaniu ustawodawczemu. Wacław Makowski opowiedział się za objęciem analogiczną ochroną Sejmu Śląskiego, komisji parlamentarnych oraz reprezentacji samorządowych. Ponadto — zdaniem

9 O genezie, charakterze prawnym, strukturze i organizacji Komisji zob. Z. Radwański, Ksztaltowanie sie polskiego systemu prawnego w pierwszych latach II Rzeczypospolitej, „Czasopismo Prawno-Historyczne" (dalej: CP-H) 21, 1969, z. 1, s. 31-44; S. Grodziski, Komisja Kodyfikacyjna Rzeczypospolitej Polskiej, CP-H 33, 1981, z. 1, s. 47-63; A. Lityński, Wydziat karny Komisji Kodyfikacyjnej II Rzeczypospolitej. Dzieje prac nad częścia ogólną kodeksu karnego, Katowice 1991, s. 11-50; M. Mohyluk, Porzadkowanie prawa w II Rzeczypospolitej: Komisja Kodyfikacyjna i Rada Prawnicza, CP-H 51, 1999, z. 1-2, s. 285-299; L. Górnicki, Prawo cywilne w pracach Komisji Kodyfikacyjnej Rzeczypospolitej Polskiej w latach 1919-1939, Wrocław 2000, s. 12-115; S. Płaza, Kodyfikacja prawa w Polsce międzywojennej, CP-H 57, 2005, z. 1, s. 219-221.

10 Protokoty obrad, Komisja Kodyfikacyjna Rzeczypospolitej Polskiej, Sekcja Prawa Karnego (dalej: SPK), t. 3, z. 1, Lwów 1925, s. 36, 52.

11 O składzie sekcji prawa karnego szerzej zob. A. Pasek, Z organizacyjnych zagadnień kodyfikacji prawa karnego w Drugiej Rzeczypospolitej, „Prawo” 288, 2004, s. 365-367.

12 Protokoty obrad..., s. 36-38. 
referenta — ochrony karnej wymagało także wykonywanie mandatów członków wszystkich organów chronionych przez ustawę ${ }^{13}$.

Juliusz Makarewicz w swoim referacie przedstawił dwa możliwe rozwiązania w zakresie ochrony czynności ustawodawczych. Pierwsze sprowadzało się do udzielenia specyficznej ochrony ciałom ustawodawczym, których charakter w ten właśnie sposób został wprost zdefiniowany w konstytucji. Drugie polegało na uwzględnieniu jako przedmiotu zamachu wszelkich ciał powołanych do wydawania wiążących norm. W wypadku przyjęcia pierwszego rozwiązania owe ciała, niemające przyznanej konstytucją władzy ustawodawczej, także korzystałyby z ochrony, ale z innego tytułu. Referent przypomniał, że w art. 2 polskiej Konstytucji ${ }^{14}$ organami narodu w zakresie ustawodawstwa były Sejm i Senat. Natomiast o prawie stanowienia w zakresie należącym do samorządu i o radach obieralnych wspominał art. 67 w rozdziale o władzy wykonawczej. Juliusz Makarewicz uważał, że z tego powodu nie można w rozdziale o przestępstwach przeciwko władzy ustawodawczej wspominać ani o sejmikach, ani o radach gminnych. $\mathrm{Z}$ kolei komisje sejmowe i senackie nie miały statusu organów ustawodawczych. Były wprawdzie emanacją ciała ustawodawczego, ale jednak o charakterze pomocniczym. Tym samym zamach na pracę komisji mógł wyjątkowo stanowić zamach pośredni na Sejm lub Senat, ale zasadniczo był wymierzony w posłów lub senatorów zajętych wykonywaniem obowiązków wynikających z mandatu parlamentarzysty ${ }^{15}$.

Z ochroną ciał ustawodawczych była związana kwestia ochrony ich członków. Zakres był tu inny niż w przypadku urzędnika wykonującego czynności urzędowe. Nie chodziło bowiem tylko o przeciwdziałanie przez sprawcę wykonywaniu czynności urzędowych przez członka organu ustawodawczego, ale o pośredni wpływ na wyniki prac ciała ustawodawczego, które rozstrzygnie sprawę w innym składzie, niż gdyby nieobecni brali udział w obradach i głosowaniu. Lwowski profesor przekonywał, że zamach na członka ciała ustawodawczego w celu utrudnienia udziału w jego pracach jest zamachem na swobodę wyrażenia woli narodu. $Z$ tego powodu zamach na członków ciała ustawodawczego należało zaliczyć do tej samej grupy stanów faktycznych co przestępstwa przeciwko ciałom ustawodawczym. Nie można było natomiast zaliczyć do tego rodzaju przestępstw czynów, które nie tworzyły przeszkody w działalności w charakterze parlamentarzysty. Nie można zatem było za nie uznać obrazy w trakcie posiedzenia czy nawet poza obradami izby z powodu stanowiska zajętego $\mathrm{w}$ głosowaniu lub wypowiadanych $\mathrm{w}$ procedowanej sprawie opinii. $Z$ kolei w przypadku rozstrzygnięcia na rzecz ochrony członków ciała ustawodawczego jako uczestników organu kolegialnego, stosując tę zasadę analogicznie do innych korporacji politycznych, niemieszczących się

13 Ibidem, s. 38, 41.

14 Ustawa z dnia 17 marca 1921 roku Konstytucja Rzeczypospolitej Polskiej (Dz.U. RP 1921 $\mathrm{Nr} 44$, poz. 634).

15 Protokoty obrad..., s. 43. 
w pojęciu „,iała ustawodawczego”, należałoby konsekwentnie rozszerzyć ochronę indywidualną także na należące do nich osoby ${ }^{16}$.

Już na początku dyskusji Prądzyński wyraził obawę, czy stworzenie przestępstwa świadomego zamachu na izby prawodawcze nie osłabi sankcji karnej za działalność podpadającą pod pojęcie zdrady stanu. Makowski przytomnie zauważył, że nie każdy zamach na pracę izb ustawodawczych jest zdradą stanu. Śliwiński opowiedział się za ochroną korporacji publicznej z powodu trudności w rozróżnianiu ciał ustawodawczych i nieustawodawczych. Z kolei Falkiewicz w ogóle nie dostrzegał potrzeby wyodrębnienia zamachów na władzę ustawodawczą, proponując łączne potraktowanie zamachów na władzę ustawodawczą, wykonawczą i sądową. Ze stanowiskiem Falkiewicza nie zgodził się Makowski, argumentując, że jakkolwiek władza jest jedna, jej funkcje są różne, dlatego należy chronić każdą $\mathrm{z}$ nich odrębnie, uwzględniając charakterystyczne cechy.

Po wyczerpaniu dyskusji nad tymi zagadnieniami uchwalono jednomyślnie wniosek Makowskiego o pozostawienie w zawieszeniu kwestii intytulacji. Z takim samym wynikiem uchwalono objęcie ochroną Sejmu, Senatu i Zgromadzenia Narodowego, Sejmu autonomicznego oraz reprezentacji samorządowych i innych korporacji prawa publicznego, zastrzegając możliwość zmiany wyrażenia „korporacje prawa publicznego" na bardziej zrozumiałe. Jednomyślnie zdecydowano także o objęciu ochroną prawną komisji sejmowych oraz posłów i członków korporacji prawa publicznego ${ }^{17}$.

Referenci przedstawili swoje stanowisko także w zakresie ujęcia działania przestępczego. Według Makowskiego działanie to polegało na wywarciu bezprawnego wpływu na bieg czynności ustawodawczych albo przez przeszkodzenie izbom w wykonaniu ich zadań, albo przez zmuszenie izb do wykonania aktów niezgodnych z ich wolą lub niezgodnych z formą wyrażania woli. Środkiem do osiągnięcia tego celu mogło być użycie przymusu fizycznego lub psychicznego, podstępu, przekupstwa lub sprzedajności. Formą przekupstwa było udzielenie korzyści materialnych lub osobistych albo ich obietnica. Z kolei formą sprzedajności było przyjęcie korzyści majątkowych lub osobistych albo ich obietnicy, a także ich żądanie. Istotą każdego z tych przypadków był nie tyle wpływ na kierunek głosowania lub stanowisko posła $\mathrm{w}$ procedowanej sprawie, ile związek czynu $\mathrm{z}$ działalnością parlamentarną ${ }^{18}$.

Makarewicz, analizując istotę działania przestępczego, odróżnił zamachy na ciało zbiorowe od zamachów indywidualnych na jego członków. W stanie faktycznym zamachu na ciało zbiorowe mieściło się każde zachowanie tworzące przeszkodę w jego należytym i sprawnym funkcjonowaniu. Referent na przykładzie kodeksów innych państw wskazał rozpędzenie ciała ustawodawczego, gwałtowne

\footnotetext{
16 Ibidem, s. 43-44.

17 Ibidem, s. 44-46.

18 Ibidem, s. 46-48.
} 
wtargnięcie do miejsca obrad i zamach na bezpieczeństwo ${ }^{19}$. Makarewicz uznał jednak za zupełnie wystarczające zastosowanie znamienia czasownikowego w postaci ,przeszkadzania w wykonywaniu funkcji”, co najwyżej z dodaniem przymiotnika „swobodnego" lub „ustawowego”. Lwowski profesor opowiedział się natomiast za dokładnym określeniem środków, za pomocą których następowało owo przeszkadzanie w pracy prawodawczej. W przeciwnym bowiem razie zaistniałaby wątpliwość, czy należy do nich zaliczyć także obstrukcyjne przemówienia lub hałasowanie.

Makarewicz podkreślił, że w przypadku zamachu na członka ciała ustawodawczego działanie z natury rzeczy różni się od zamachu na ciało ustawodawcze. W pierwszym przypadku chodziło o przeszkodzenie indywidualnie oznaczonej osobie w normalnym braniu udziału w pracach ustawodawczych, na przykład przez usunięcie z sali obrad, utrudnianie wypowiedzi lub udziału w głosowaniu. Sposobem działania sprawcy także w tym przypadku był gwałt lub groźba.

Swoistą rolę w odniesieniu do członków organów ustawodawczych odgrywało - w ocenie Makarewicza — przekupstwo. Nie miał wątpliwości, że prowadziło ono do tego samego celu co gwałt lub groźba - wpływu na wolę. Jednocześnie wskazał jednak na skomplikowany charakter tego zagadnienia z punktu widzenia kodeksowej systematyki ${ }^{20}$.

W trakcie dyskusji po wysłuchaniu referentów Witold Prądzyński zgłosił wątpliwość, czy wystarczy samo pojęcie groźby, czy też należałoby wprowadzić pojęcie groźby karalnej. Makowski jednoznacznie poparł ograniczenie przesłanki odpowiedzialności do groźby karalnej, a ponadto wypowiedział się przeciwko

19 W swoim wystąpieniu na forum sekcji prawa karnego Makarewicz stwierdził: „Przy zamachu na ciało zbiorowe wysuwa się na pierwszy plan wszystko, co stoi na przeszkodzie należytemu i sprawnemu funkcjonowaniu tego ciała. Dlatego niektóre ustawy zaczynają wyliczenie sposobów działania chronologicznie od przeszkodzenia zebraniu się lub ukonstytuowaniu się (portugal. 171, meksykański 1095 III, finlandzki r. 15 § 1, k.k. dla New York § 59), inne znów podkreślają wypadki szczególnie drastyczne, jak rozpędzenie ciała ustawodawczego (tak k.k. niemiecki 105, holenderski 121, 123), albo omawiają kazuistycznie sposoby przeszkadzania lub wpływania na obrady; mówi się wtedy o wtargnięciu gwałtownym lub przy użyciu groźby do pałacu, w którym odbywają się zebrania, albo o urządzeniu zgromadzeń manifestacyjnych w pobliżu (k.k. hiszpański 167-169), albo mówi się o zamachu na bezpieczeństwo (k.k. duński 95), o gwałtownych działaniach (k.k. portugalski 171 1.4)" — ibidem, s. 48.

20 „Sprawa z punktu widzenia systematyki wikła się tutaj o tyle, że na pierwszy plan wysuwa się osoba biorąca podarunek, większą jest wina deputowanego przyjmującego podarunek, by stosownie do tego oddać swój głos lub w inny sposób wyzyskiwać swe stanowisko, niż wina dającego podarunek. Jeżeli zgodzić się można na to, że ofiarujący podarunek pośrednio dopuszcza się zamachu na władzę ustawodawczą państwa, to wina deputowanego czy senatora przekupnego jest inną, on nie dopuszcza się żadnego zamachu, on narusza swe obowiązki zawodowe, tak samo jak urzędnik w identycznej sytuacji. Z tych względów wiązanie przekupstwa parlamentarnego z zamachami na ciała ustawodawcze nie jest trafne. Sprawa ta wiąże się raczej z przestępstwami urzędniczymi, kodyfikacyjnie nie natrafia to na trudności, gdyż od ustawy zależy, czy parlamentarzystę podciągnie pod pojęcie osoby urzędowej" - ibidem, s. 50. 
traktowaniu przekupstwa posła na równi z przekupstwem urzędnika ze względu na specyficzny charakter działalności parlamentarzysty. Argumentował, że urzędnik rozstrzyga swą decyzją konkretną sprawę, podczas gdy poseł wpływa na kształt podstawowych kwestii ustroju państwowego. Kałużniacki podzielił pogląd Makowskiego, ponieważ uważał, że zastosowanie w stosunku do posłów przepisów urzędniczych nie godzi się z poczuciem społecznym, które nigdy nie traktuje posła jak urzędnika. Śliwiński także poparł sprecyzowanie groźby przez dodanie przymiotnika określającego, a ponadto zaproponował wprowadzenie pojęcia „podstęp”. Makarewicz wypowiedział się za utrzymaniem „groźby” bez żadnego dodatku, aby w ten sposób zachować jej jak najszerszy zakres. Natomiast w celu uniknięcia luki w kodeksie zaakceptował dodanie „podstępu”. W tej drugiej kwestii polemiczne stanowisko zajął z kolei Makowski, wskazując, że trudno będzie ów „podstęp” prawidłowo zdiagnozować. Jeżeli bowiem skutkiem podstępu będzie pomyłka w tekście ustawy, odpowiedzialny za nią będzie Sejm, zobowiązany do staranności przy opracowywaniu tekstu aktu prawnego, a nie osoby postronne ${ }^{21}$.

Po wyczerpaniu dyskusji najpierw uchwalono, że:

— działanie przeciw ciałom zbiorowym polega na przeszkadzaniu w swobodnym wykonywaniu funkcji (środki: gwałt i groźba);

- działanie przeciw członkom ciał zbiorowych polega na przeszkadzaniu w swobodnym wykonywaniu czynności (środki: gwałt i groźba).

Następnie przewodniczący Makarewicz poddał pod głosowanie, czy poprzestać na pojęciu groźby, czy zastosować wyrażenie „groźba karalna” lub „groźba bezprawna”. Za „groźbą” oddano 1 głos, za „groźbą karalną” — 2, a za „groźbą bezprawną" - 4 głosy. Wobec tego wyniku przyjęte zostało pojęcie groźby bezprawnej. Następnie rozstrzygano, czy wprowadzić oprócz pojęcia gwałtu i groźby pojęcie podstępu lub przekupstwa. W głosowaniu za wprowadzeniem „podstępu” padł 1 głos, za wprowadzeniem „przekupstwa” także 1 głos. W konsekwencji przewodniczący ustalił, że oba wnioski upadły ${ }^{22}$.

Uchwały podjęte przez sekcję prawa karnego w dniu 20 stycznia 1925 roku były podstawą stanów faktycznych opisanych w artykułach 19-20 Projektu wstępnego części szczególnej kodeksu karnego opracowanego przez W. Makowskiego ${ }^{23}$ oraz w artykułach 106 i 107 § Projektu wstęnnego części szczegółowej kodeksu karnego przygotowanego przez J. Makarewicza ${ }^{24}$.

Wacław Makowski zaznaczył w uwagach wprowadzających, że dążył w swoim wstępnym projekcie części szczególnej kodeksu karnego do możliwie jak naj-

21 Ibidem, s. 46-51.

22 Ibidem, s. 51-52.

23 Projekt wstępny części szczególnej kodeksu karnego opracowany z polecenia Sekcji Prawa Karnego Komisji Kodyfikacyjnej przez Profesora Wacława Makowskiego, SPK, t. 4, z. 1, Warszawa 1926. s. 9-10.

24 Projekt wstępny części szczegółowej kodeksu karnego opracowany przez redaktora głównego Prof. Dr. Juliusza Makarewicza, SPK, t. 4, z. 2, Lwów 1926, s. 8-9. 
szerszego zastosowania uchwał sekcji, odstępując od nich tylko w tych przypadkach, gdy w jego przekonaniu ścisłe uwzględnienie treści uchwały nie dałoby się konsekwentnie przeprowadzić, lub gdy sama uchwała nie miała stanowczego charakteru. Autor uważał przedłożony projekt tylko za materiał do dalszej, szczegółowej dyskusji ${ }^{25}$.

Makowski umieścił dwa artykuły w części III swojego projektu zatytułowanej Przestępstwa przeciwko zrzeszeniom prawa publicznego. W art. 19 ujęta została przemoc względem zrzeszeń prawa publicznego. Zgodnie z § 1

kto przemocą lub groźbą bezprawną wywiera wpływ na czynności prawne Sejmu, Senatu, Zgromadzenia Narodowego, Sejmu autonomicznego, albo Naczelnej Izby Gospodarczej, albo im przeszkadza, ulega karze pozbawienia wolności od 1 roku do 5 lat

\section{Z kolei w myśl art. 19 § 2}

kto przemocą lub groźbą bezprawną wywierał wpływ na czynności prawne innych, prócz wymienionych w $\S 1$ zrzeszeń prawa publicznego, albo im przeszkadzał, ulegał karze pozbawienia wolności do lat 3 .

Następny artykuł (art. $20 \S 1$ ) dotyczył przemocy względem członków zrzeszeń prawa publicznego. Głosił on, że

kto przemocą lub groźbą bezprawną: a) powstrzymuje posła, senatora lub członka Naczelnej Izby Gospodarczej od udziału w głosowaniu lub w innych pracach Sejmu, Senatu, Zgromadzenia Narodowego lub Naczelnej Izby Gospodarczej; b) wywiera wpływ na sposób ich głosowania lub wykonywania przez nich prac, związanych z włożonym na nich mandatem, ulega karze pozbawienia wolności do lat 5 .

Natomiast w kolejnym paragrafie przepis ten stanowił, że

kto gwałtem lub groźbą bezprawną: a) powstrzymuje członka zrzeszenia prawa publicznego niewymienionego w § 1 od udziału w głosowaniu lub w pracach tego zrzeszenia; b) wywiera wpływ na sposób głosowania lub wykonywania przez członka zrzeszenia prawa publicznego prac, związanych z włożonym na niego mandatem, ulega karze pozbawienia wolności do lat $3^{26}$.

Na podstawie tych samych uchwał sekcji prawa karnego dwa stany faktyczne skonstruował koreferent Juliusz Makarewicz. Autor zawarł je w części V swojego projektu wstępnego części szczegółowej kodeksu karnego razem z innymi przestępstwami przeciw władzy państwowej. Uchwały sekcji były szeroką platformą, wspólną dla obu redaktorów, sięgającą nieraz aż do ustalenia szczegółowego brzmienia konkretnego przepisu. Wytworzyły one też między dwoma projektami liczne punkty styczne. Istniały jednak także rozbieżności zarówno w samym układzie projektów, którego sekcja nie omawiała, jak i w zakresie szczegółów techniki kodyfikacyjnej. Makarewicz uważał część szczególną kodeksu za ciąg

${ }^{25}$ Projekt wstępny części szczególnej kodeksu karnego opracowany z polecenia Sekcji Prawa Karnego..., s. 1.

${ }^{26}$ Ibidem, s. 9-10. 
dalszy części ogólnej, dlatego zaczął jej artykułowanie od numeru 86 jako kolejnej przypadającej liczby porządkowej ${ }^{27}$.

Stosownie do $§ 1$ i 2 art. 106 projektu Makarewicza

kto przemocą lub zagrożeniem użycia przemocy uniemożliwiał wykonywanie władzy Prezydenta Rzeczypospolitej, Zgromadzenia Narodowego, Rady Ministrów, Senatu, Sejmu, sejmiku lub sądu, albo kto przeszkadzał w wykonywaniu tej władzy, albo użycia jej w oznaczonym kierunku zniewalał, ponosił karę więzienia. Jeżeli działanie skierowane było przeciw zrzeszeniom prawa publicznego innym, niż wymienione w $§ 1$, winny ponosił karę więzienia do lat pięciu.

Natomiast przepis art. $107 \S 1$ stanowił, że

kto przemocą lub zagrożeniem użycia przemocy uniemożliwia wykonywanie władzy ministra lub jego zastępcy, posła, senatora, przedstawiciela wojewódzkiej władzy samorządowej lub sędziego, w wykonywaniu tej władzy przeszkadza lub do wykonywania w oznaczonym kierunku zniewala, ponosi karę więzienia ${ }^{28}$.

Konstrukcje zaproponowane przez obu autorów były następnie podstawą czterech stanów faktycznych zawartych w rozdziale III Projektu części szczególnej kodeksu karnego $w$ redakcji przyjętej $w$ pierwszym czytaniu ${ }^{29}$ zatytułowanym Przestępstwa przeciwko zrzeszeniom prawa publicznego ${ }^{30}$. W konsekwencji opracowany przez sekcję prawa karnego rozdział III był swoistą kompilacją odpowiednich rozdziałów projektów wstępnych części szczególnej kodeksu karnego opublikowanych wcześniej przez Makowskiego i Makarewicza. Otwierał go przepis art. 23, przewidujący karę więzienia do lat 10 dla każdego, kto przemocą lub groźbą bezprawną wywierał wpływ na czynności Sejmu, Senatu, Zgromadzenia Narodowego lub Sejmu autonomicznego bądź tym czynnościom przeszkadzał.

$\mathrm{Na}$ podstawie art. 24 kara więzienia do lat 5 groziła sprawcy, który przemocą lub groźbą bezprawną bądź wywierał wpływ na czynności innych, oprócz wymienionych $\mathrm{w}$ art. 23, zrzeszeń prawa publicznego, bądź tym czynnościom przeszkadzał. W myśl art. 25 kto przemocą lub groźbą bezprawną bądź wywierał wpływ na wykonywanie mandatu posła, senatora lub członka Sejmu autonomicznego, bądź temu wykonywaniu przeszkadzał, podlegał karze więzienia do lat 10 . $\mathrm{Z}$ kolei zgodnie z art. 26 sprawca, który przemocą lub groźbą bezprawną wywierał wpływ na wykonywanie mandatu członka zrzeszenia prawa publicznego, innego

27 Projekt wstępny części szczegółowej kodeksu karnego opracowany przez redaktora głównego..., s. 3-4.

28 Ibidem, s. 8.

29 Projekt został zredagowany w latach 1927-1928 - J. Jamontt, E.S. Rappaport, R. Lemkin, Kodeks karny r. 1932 z dostosowanymi do kodeksu tezami z orzeczeń Sądu Najwyższego, odpowiednimi ustępami uzasadnienia projektu Komisji Kodyfikacyjnej oraz ze skorowidzem, Warszawa 1932, s. 14.

30 Projekt części szczególnej kodeksu karnego w redakcji przyjętej w pierwszym czytaniu, SPK, t. 4, z. 3, Lwów 1929, s. 8. 
niż wymienione w art. 25, lub temu wykonywaniu przeszkadzał, podlegał karze więzienia do lat $5^{31}$.

W ramach drugiego czytania projektu całego kodeksu karnego zestawiono w jedną całość część ogólną i szczególną, dlatego zmienił się numer rozdziału (z III na XVIII), oraz numery zawartych w nim artykułów (z 23-26 na 108-111). Natomiast nie zmienił się tytuł; nadal były to Przestęsstwa przeciwko zrzeszeniom prawa publicznego. W drugim czytaniu do przepisów rozdziału ustalonych w pierwszym czytaniu nie wprowadzono żadnych zmian merytorycznych ani redakcyjnych ${ }^{32}$. Uzasadnienie do rozdziału XVIII sporządził Wacław Makowski.

Rozdział XVIII w projekcie polskiego kodeksu karnego był udaną próbą nowoczesnego ujęcia ochrony prawnej insty tucji prawa publicznego. Koncepcja tych przepisów została oparta na założeniu, że państwo należy traktować jako organizację zbiorowości. Do kategorii takich elementów organizacyjnych zaliczono także izby ustawodawcze. Zarówno samo ich istnienie, jak i ochrona karnoprawna musiały wynikać z istoty zorganizowanego współżycia i roli, którą miały w nim do wypełnienia. Ta rola organizacyjna nie mogła być utożsamiona ani z pojęciem władzy jako uprawnień fikcyjnego podmiotu osobowości państwowej, ani z podmiotowymi prawami obywateli. Charakterystyczna dla nowożytnego prawoznawstwa obiektywizacja pojęć prawnych została odzwierciedlona w stwierdzeniu samodzielnej roli prawnopublicznej zgromadzenia ustawodawczego. Skoro jednak potraktowano izby ustawodawcze jako organ współżycia ludzkiego, to uznając ich czołowe miejsce, należało zarazem założyć możliwość istnienia obok nich innych zgromadzeń czy zrzeszeń publicznoprawnych o zakresie działania może mniej rozległym albo mniej samodzielnym, ale mających ten sam charakter organów państwowych ${ }^{33}$.

Organizacja państwowa dąży do rozbudowania całego systemu zrzeszeń publicznoprawnych. Projekt polskiego kodeksu dążył z kolei do zapewnienia ochrony karnoprawnej tym instytucjom, których działalność była wyrazem organizacji nowożytnego państwa. Przedmiotem przestępstw zawartych w rozdziale XVIII projektu przyjętego $\mathrm{w}$ drugim czytaniu były zrzeszenia prawa publicznego. Pod tym pojęciem rozumiano państwo oraz poszczególne zbiorowości, powołane w ramach państwa do wykonywania różnych funkcji życia zbiorowego. W tym rozumieniu zrzeszeniami prawnopublicznymi były parlamenty — zarówno w całości, jak i poszczególne ich części (na przykład komisje parlamentarne). Mieściły się w tym pojęciu także instytucje samorządu lokalnego i celowego (zawodowego, gospodarczego). Przedmiotem ochrony rozdziału XVIII nie była władza

31 Ibidem.

32 Projekt kodeksu karnego w redakcji przyjętej $w$ drugim czytaniu przez Sekcję Prawa Karnego Komisji Kodyfikacyjnej RP, SPK, t. 5, z. 2, Warszawa 1930, s. 27-28.

33 Projekt kodeksu karnego w redakcji przyjętej $w$ drugim czytaniu przez Sekcję Prawa Karnego Komisji Kodyfikacyjnej RP. Uzasadnienie części szczególnej, SPK, t. 5, z. 4, Warszawa 1930, s. 23,26 . 
ustawodawcza w swojej istocie, ale normalny bieg czynności tych zrzeszeń, to jest należyte wykonywanie zadań, do których zostały one powołane. Zestawiając w jednym rozdziale wszystkie zrzeszenia publicznoprawne, projekt uznał jednak za konieczne wyróżnienie tych, które miały powszechny charakter, a będąc powołane do stanowienia ustaw oraz innych czynności istotnych z punktu widzenia funkcjonowania państwa, wymagały również szczególnej ochrony. $Z$ tego powodu w art. 108 kazuistycznie wyróżnione zostały: Sejm, Senat, Zgromadzenie Narodowe, Sejm autonomiczny. Następny artykuł mówił już ogólnie o innych, oprócz wymienionych, zrzeszeniach prawa publicznego, nie wymieniając ich szczegółowo, pozostawiając ustalenie ich charakteru odpowiednim aktom prawa publicznego. Było to konieczne, ponieważ należało uwzględnić powoływanie i rozbudowę coraz nowszych zrzeszeń tego rodzaju ${ }^{34}$.

W art. 108-111 przedmiotem przestępstwa była czynność, jaką podejmowało, zamierzało podjąć lub obawiało się podjąć chronione zrzeszenie publicznoprawne. Projekt nie mówił ani o uchwałach, ani o posiedzeniach czy zgromadzeniach plenarnych, przyjmując, że taka kazuistyka dawałaby pretekst do podnoszenia wątpliwości w zakresie granic ochrony karnoprawnej. Pod pojęcie czynności podpadało wszystko to, co wykonywano na podstawie normy prawnej określającej organizację, kompetencje i tryb postępowania prawnego danego zrzeszenia bez względu na to, czy brali w nim udział wszyscy członkowie, czy też pewna ich liczba, czy liczba uczestników tworzyła quorum zgromadzenia plenarnego, komisji, prezydium i tym podobnych organów wewnętrznych zrzeszenia. Nie miało również znaczenia miejsce podjęcia czynności prawnych przez zrzeszenie. Czynnością była nie tylko uchwała stanowcza, ale także każda uchwała wstępna oraz każda czynność niezbędna do jej podjęcia lub wykonania ${ }^{35}$.

Zamach na czynności zrzeszeń w rozumieniu art. 108 i 109 mógł zmierzać w dwóch kierunkach: 1. albo do przeszkodzenia w podjęciu lub dokonaniu podjętej czynności w ogólności, przy czym było obojętne, czy skutek ten został osiągnięty; 2. albo nadania czynnościom kierunku niezgodnego z wolą zrzeszenia. Te formy działania zostały określone jako przeszkadzanie czynnościom lub wywieranie na nie wpływu. W obydwu przypadkach warunkiem wyczerpania znamion przestępstwa był bezprawny sposób działania. Jeśli bowiem sprawca starał się wywrzeć wpływ na przebieg obrad lub uchwał zgromadzenia argumentami lub wywodami w celu przekonania obradujących do swojego stanowiska, to tego rodzaju działanie nie zawierało cech przestępstwa. Karygodnym środkiem działania było natomiast zastosowanie przemocy lub groźby bezprawnej. Przemocą było użycie siły fizycznej w jakiejkolwiek postaci, analogicznie jak przy innych stanach faktycznych przestępstw opartych na elemencie przemocy (na przykład zbrodnie stanu, zmuszenie). Groźbą bezprawną był przymus psychiczny charakteryzujący się

34 Ibidem, s. 26-28.

35 Ibidem, s. 28-29. 
cechami odpowiadającymi pojęciu groźby karalnej w myśl art. 242 projektu. Zarówno przemoc, jak i groźba bezprawna musiały charakteryzować działanie przestępne, którego istotą było wywieranie wpływu na czynności lub przeszkadzanie czynnościom zrzeszenia publicznoprawnego. Tym samym zarówno przemoc, jak i groźba mogły być wymierzone albo przeciwko całości zrzeszenia, pełnemu lub częściowemu jego zgromadzeniu, albo przeciwko poszczególnym jego organom, w sposób mogący wpłynąć lub przeszkodzić ich prawidłowemu funkcjonowaniu ${ }^{36}$.

Oprócz zamachów na czynności zrzeszeń publicznoprawnych rozumianych jako instytucje w całości projekt typizował w artykułach 110 i 111 te same działania przestępcze w stosunku do ich członków. Wyróżniono tu również z jednej strony kazuistycznie posłów, senatorów i członków Sejmu autonomicznego, z drugiej zaś członków innych zrzeszeń publicznoprawnych. Punktem wyjścia tych stanów faktycznych ponownie nie była koncepcja subiektywnych praw ani przedstawicieli, ani ich mandatariuszy. Ochrona karnoprawna miała tu na względzie raczej obiektywną normę prawną i zapatrywała się na członków zrzeszenia jako na jego czynnik składowy. Odróżnienie zamachów na poszczególnych członków od zamachów na zrzeszenie opierało się nie na odmiennej koncepcji prawnej, tylko na faktycznej konieczności osobnego ujęcia zamachów o innym zakresie. Groźba skierowana przeciwko konkretnemu posłowi w celu zmuszenia go do głosowania w oczekiwany przez sprawcę sposób nie była wprawdzie zamachem bezpośrednio na izbę poselską, ale na gruncie oceny karnoprawnej obydwie te formy działania przestępczego pozostawały z sobą w ścisłym związku. Obydwie te formy zamachów projekt potraktował jednakowo pod względem konstrukcji prawnej oraz sankcji karnej, utrzymując konsekwentnie jako punkt wyjścia zasadę ochrony zrzeszeń publicznych i ich członków w związku z ich obiektywną rolą w życiu społeczności ${ }^{37}$.

$\mathrm{W}$ ramach trzeciego czytania projektu ${ }^{38} \mathrm{z}$ powodu modyfikacji innych przepisów po raz kolejny ustalono nowy numer rozdziału (XIX) oraz nowe numery artykułów (112-115). Treść przepisów nie zmieniła się, ale w uzupełnieniu uzasadnienia do art. 112 i 113 (poprzednio 108 i 109) sprecyzowano, że według rozumienia sekcji groźba bezprawna, wymieniona w opisie tych stanów faktycznych jako środek działania, odpowiadała wprawdzie co do swoich cech podstawowych pojęciu groźby karalnej w myśl art. 247 (uprzednio art. 242), ale nie była z nią równoznaczna. Pojęcie groźby bezprawnej na gruncie artykułów 112-113 było szersze i mogło obejmować także przypadki nieobjęte art. $247^{39}$.

Była to ostateczna wersja stanów faktycznych Przestępstw przeciwko głosowaniu $w$ sprawach publicznych, zawartych w ukończonym projekcie kodeksu

36 Ibidem, s. 29-30.

37 Ibidem, s. 30.

38 Projekt kodeksu karnego w redakcji przyjętej w trzecim czytaniu przez Sekcję Prawa Karnego Komisji Kodyfikacyjnej RP, SPK, t. 5, z. 5, Warszawa 1931, s. 24-25.

39 Uzupetnienie uzasadnienia projektu kodeksu karnego, SPK, t. 5, z. 6, Warszawa 1931, s. 20. 
karnego, przekazanym Ministrowi Sprawiedliwości przez sekretarza generalnego Komisji Kodyfikacyjnej Stanisława Emila Rappaporta we wrześniu 1931 roku ${ }^{40}$. $\mathrm{W}$ toku dalszych prac ustawodawczych ${ }^{41}$ nie dokonano już żadnych zmian poza nową numeracją rozdziału i zawartych w nim artykułów oraz złagodzeniem sankcji za niektóre przestępstwa ${ }^{42}$. W tej wersji przepisy te weszły w życie wraz z całym kodeksem karnym w dniu 11 września 1932 roku na mocy rozporządzenia Prezydenta Rzeczypospolitej z dnia 11 lipca 1932 roku ${ }^{43}$.

\section{Bibliografia}

\section{Źródła}

\section{Akty prawne}

Dekret Naczelnego Dowódcy Józefa Piłsudskiego z dnia 14 listopada 1918 roku (Dz. Praw P. Pol. z 1918 r. Nr 17, poz. 40).

Dekret z dnia 22 listopada 1918 roku o najwyższej władzy reprezentacyjnej Republiki Polskiej (Dz. Praw P. Pol. z 1918 r. Nr 17, poz. 41).

Dekret z dnia 28 listopada 1918 roku o ordynacji wyborczej do Sejmu Ustawodawczego (Dz. Praw P. Pol. z 1918 r. Nr 18, poz. 46).

Dekret Naczelnika Państwa z dnia 8 stycznia 1919 roku o postanowieniach karnych za przeciwdziałanie wyborom do Sejmu i wykonywanie obowiązków poselskich (Dz. Praw P. Pol. z 1919 r. Nr 5, poz. 96).

Rozporządzenie Prezydenta Rzeczypospolitej z dnia 11 lipca 1932 roku Kodeks karny (Dz.U. RP z 1932 r. Nr 60, poz. 571).

Rozporządzenie Prezydenta Rzeczypospolitej z dnia 11 lipca 1932 roku Przepisy wprowadzające kodeks karny i prawo o wykroczeniach (Dz.U. RP z 1932 r. Nr 60, poz. 573.

Ustawa z dnia 17 marca 1921 roku Konstytucja Rzeczypospolitej Polskiej (Dz.U. RP z 1921 r. Nr 44, poz. 634).

40 J. Jamontt, E.S. Rappaport, R. Lemkin, op. cit., s. 15.

${ }^{41}$ Do oceny projektu powołana została Komisja Ministerialna w składzie: podsekretarz stanu S. Sieczkowski (przewodniczący) oraz L. Bekerman, J. Gumiński, J. Jamontt, W. Kuczyński, S. Lubodziecki, W. de Michelis i A. Miller. Pracowała ona do marca 1932 roku. W dniach 9-10 marca 1932 roku minister sprawiedliwości C. Michałowski zorganizował specjalną naradę z udziałem części członków Komisji Ministerialnej oraz nieuczestniczącymi wcześniej w jej posiedzeniach sekretarzem generalnym Komisji Kodyfikacyjnej S.E. Rappaportem i głównymi referentami, J. Makarewiczem i W. Makowskim. W trakcie wspólnych narad ustalono ostateczny tekst projektu kodeksu karnego w postaci, w której Minister Sprawiedliwości zamierzał wprowadzić go w życie J. Jamontt, E.S. Rappaport, R. Lemkin, op. cit., s. 17-19.

42 Złagodzenie sankcji polegało na wprowadzeniu alternatywnej kary aresztu oraz obniżeniu górnego, ustawowego wymiaru kary więzienia.

43 Rozporządzenie Prezydenta Rzeczypospolitej z dnia 11 lipca 1932 roku Kodeks karny (Dz.U. RP z 1932 r. Nr 60, poz. 571). 


\section{Projekty aktów prawnych}

Projekt części szczególnej kodeksu karnego w redakcji przyjętej w pierwszym czytaniu, Komisja Kodyfikacyjna Rzeczypospolitej Polskiej, Sekcja Prawa Karnego, t. 4, z. 3, Lwów 1929.

Projekt kodeksu karnego w redakcji przyjętej w drugim czytaniu przez Sekcję Prawa Karnego Komisji Kodyfikacyjnej RP, Komisja Kodyfikacyjna Rzeczypospolitej Polskiej, Sekcja Prawa Karnego, t. 5, z. 2, Warszawa 1930.

Projekt kodeksu karnego w redakcji przyjętej w drugim czytaniu przez Sekcję Prawa Karnego Komisji Kodyfikacyjnej RP. Uzasadnienie części szczególnej, Komisja Kodyfikacyjna Rzeczypospolitej Polskiej, Sekcja Prawa Karnego, t. 5, z. 4, Warszawa 1930.

Projekt kodeksu karnego w redakcji przyjętej w trzecim czytaniu przez Sekcję Prawa Karnego Komisji Kodyfikacyjnej RP, Komisja Kodyfikacyjna Rzeczypospolitej Polskiej, Sekcja Prawa Karnego, t. 5, z. 5, Warszawa 1931.

Projekt wstępny części szczegółowej kodeksu karnego opracowany przez redaktora głównego Prof. Dr. Juliusza Makarewicza, Komisja Kodyfikacyjna Rzeczypospolitej Polskiej, Sekcja Prawa Karnego, t. 4, z. 2, Lwów 1926.

Projekt wstępny części szczególnej kodeksu karnego opracowany z polecenia Sekcji Prawa Karnego Komisji Kodyfikacyjnej przez Profesora Wactawa Makowskiego, Komisja Kodyfikacyjna Rzeczypospolitej Polskiej, Sekcja Prawa Karnego, t. 4, z. 1, Warszawa 1926.

Uzupetnienie uzasadnienia projektu kodeksu karnego, Komisja Kodyfikacyjna Rzeczypospolitej Polskiej, Sekcja Prawa Karnego, t. 5, z. 6, Warszawa 1931.

\section{Źródła drukowane}

Protokoły obrad, Komisja Kodyfikacyjna Rzeczypospolitej Polskiej, Sekcja Prawa Karnego, t. 3, z. 1, Lwów 1925.

\section{Literatura}

Górnicki L., Prawo cywilne w pracach Komisji Kodyfikacyjnej Rzeczypospolitej Polskiej w latach 1919-1939, Wrocław 2000.

Grodziski S., Komisja Kodyfikacyjna Rzeczypospolitej Polskiej, CP-H 33, 1981, z. 1.

Jamontt J., Rappaport E.S., Lemkin R., Kodeks karny r. 1932 z dostosowanymi do kodeksu tezami z orzeczeń Sądu Najwyższego, odpowiednimi ustępami uzasadnienia projektu Komisji Kodyfikacyjnej oraz ze skorowidzem, Warszawa 1932.

Koredczuk J., Przestepstwa przeciwko wyborom i glosowaniu w polskim prawie karnym XX wieku, „Opolskie Studia Administracyjno-Prawne” 14, 2016, nr 2.

Lityński A., Wydział karny Komisji Kodyfikacyjnej II Rzeczypospolitej. Dzieje prac nad częścia ogólna kodeksu karnego, Katowice 1991.

Mohyluk M., Porzadkowanie prawa w II Rzeczypospolitej: Komisja Kodyfikacyjna i Rada Prawnicza, CP-H 51, 1999, z. 1-2.

Pasek A., Z organizacyjnych zagadnień kodyfikacji prawa karnego w Drugiej Rzeczypospolitej, „Prawo” 288, 2004.

Płaza S., Kodyfikacja prawa w Polsce międzywojennej, CP-H 57, 2005, z. 1.

Radwański Z., Ksztattowanie się polskiego systemu prawnego w pierwszych latach II Rzeczypospolitej, CP-H 21, 1969, z. 1. 


\title{
Offences against public law associations in the draft Criminal Code of the Codification Commission of the Republic of Poland
}

\begin{abstract}
Summary
The article examines the work in the criminal law section of the Codification Commission of the Republic of Poland on the construction of the factual circumstances of offences against public law associations. The analysis is based on the papers delivered during a meeting of the section by Wacław Makowski and Juliusz Makarewicz. The proposals presented in them were used in the final version of Chapter XIX of the draft Polish Criminal Code. The author demonstrates that the construction of the offences in question was shaped by in-depth discussions within the criminal law section. Their objective was to create a modern form of protection of public law associations in the Criminal Code.
\end{abstract}

Keywords: Codification Commission, Juliusz Makarewicz, draft criminal code, public law association

\section{Straftaten gegen Vereinigungen öffentlichen Rechtes in dem Entwurf des Strafgesetzbuches der Kodifikationskommission der Republik Polen}

\section{Zusammenfassung}

In der Bearbeitung wurde der Ablauf der Arbeit in der Sektion Strafrecht der Kodifikationskommission der Republik Polen betreffend die Konstruktion der Sachverhalte der Straftaten gegen die Vereinigungen öffentlichen Rechtes geschildert. Gegenstand der Diskussion und der Analyse stellten die Referate dar, die während der Beratungen der Sektion durch die Herren Wacław Makowski und Juliusz Makarewicz vorgetragen wurden. Ihre Vorschläge wurden bei der endgültigen Ausgestaltung des Kapitels 19. des Entwurfes des polnischen Strafgesetzbuches angewandt. Es wurde bewiesen, dass vertiefte Überlegungen im Rahmen der Sektion für Strafrecht der Konstruktion der besprochenen Straftaten zugrunde lagen. Sie verfolgten das Ziel, den Schutz der Vereinigungen öffentlichen Rechtes im Strafgesetzbuch modern zu erfassen.

Schlüsselwörter: Kodifikationskommission, Juliusz Makarewicz, Entwurf des Strafgesetzbuches, Vereinigungen öffentlichen Rechtes (Sejm, Senat, Nationalversammlung, autonomer Sejm) 